\title{
MANAJEMEN SARANA DAN PRASARANA PENDIDIKAN
}

Mukhroji

Dosen Luar Biasa STAIN Purwokerto

\begin{abstract}
The facility is a direct means to reach a goal. And infrastructure is an indirect means to reach a goal. Educational facilities and infrastructure management is the control and utilization of all the factors and resources either directly or indirectly with the planning necessary to achieve educational goals. With the good management of facilities and infrastructure, each institution can improve the quality of education with a reliable output. And the use of appropriate facilities and infrastructure can make an institution successful and still exist in today's era of globalization.
\end{abstract}

Key words: Management, Facilities - Infrastructure, and Quality of Education.

\section{Pendahuluan}

Pemberlakuan Undang-Undang No. 22 Tahun 1999 tentang Otonomi Daerah mengisyaratkan mengenai kemungkinan-kemungkinan pengembangan suatu wilayah dalam suasana yang lebih kondusif dan dalam wawasan yang lebih demokratis. Termasuk di dalamnya, berbagai kemungkinan pengelolaan dan pengembangan bidang pendidikan. Pemberlakuan UU tersebut menuntut adanya perubahan pengelolaan pendidikan dari yang bersifat sentralistik sampai yang bersifat desentralistik (Chan, 2005:1).

Desentralisasi pendidikan merupakan suatu keharusan. Ada tiga hal yang berkaitan dengan dengan urgensi desentralisasi pendidikan. Ketiga hal tersebut adalah a) pembangunan masyarakat demokrasi, b) pengembangan social capital, dan c) peningkatan daya saing bangsa (Tilaar, 2002:20). Ketiga hal tersebut sudah lebih dari cukup untuk dijadikan sebagai alasan mengapa desentralisasi pendidikan harus dilakukan oleh Bangsa Indonesia. 
Akan tetapi, masih banyak daerah yang belum siap untuk menerima berbagai kewenangan dengan adanya pemberlakuan otonomi daerah, termasuk menjalankan kewenangan bidang pendidikan ini. Alasan yang sering terdengar yang digunakan oleh daerah tersebut diantaranya a) sumber daya manusia (SDM) mereka belum memadai, b) sarana prasarana mereka belum tersedia, c) anggaran pendapatan asli daerah (PAD) mereka sangat rendah, d) secara psikologis, mental mereka terhadap sebuah perubahan belum siap, e) mereka juga gamang atau takut terhadap upaya pembaruan (Tilaar, 2000: 6-18).

Lalu bagaimana daerah dan lembaga pendidikan yang ada menyambut adanya otonomi daerah tersebut, terutama dalam pengembangan sarana dan prasarana pendidikan. Dan bagaimana manajemen sarana dan prasarana dalam pendidikan.

\section{Otonomi Daerah dan Desentralisasi Pendidikan}

Terminologi desentralisasi mengemuka pertama kali pada tahun 1974 bersama dengan disusunnya UU Nomor 5 Tahun 1974 dan menjadi wacana publik dengan dikeluarkannya UU Nomor 22 tahun 1999 mengenai kewenangan Pemerintah daerah. Bab I tentang Ketentuan Umum Pasal 1 butir c menyebutkan bahwa "desentralisasi adalah penyerahan wewenang pemerintahan oleh Pemerintah kepada Daerah Otonom dalam kerangka NKRI". Di samping itu juga beberapa aturan mengenai otonomi daerah diungkap dalam UUNomor 25 Tahun 1999 tentang Perimbangan Keuangan antara Pemerintah Pusat dan Daerah dan PP Nomor 25 tahun 2000 tentang Kewenangan Pemerintah Pusat dan Kewenangan Propinsi sebagai daerah otonom.

Dalam pasal 11 ayat 2 UU Nomor 22 Tahun 1999 menyebutkan bahwa pendidikan dan kebudayaan telah ditetapkan sebagai salah satu bidang pemerintahan yang wajib dilaksanakan oleh pemerintah kabupaten/ kota. Dan tujuan dilimpahkannya pelaksanaan pendidikan kepada pemerintah daerah (Pemda) seperti yang tercantum dalam konsideran UU nomor 22 Tahun 1999, adalah untuk memberikan pelayanan pendidikan yang lebih menekankan pada prinsip-prinsip demokrasi, peran serta masyarakat, pemerataan, dan keadilan serta memperhatikan potensi dan keanekaragaman daerah dengan tanpa mengabaikan persaingan dunia 
global (global village). Melalui UU di atas, pendidikan diharapkan berorientasi kepada mutu, relevan dengan kondisi global dan kebutuhan daerah, dan merata pada masyarakat setempat. Untuk memenuhi maksud tersebut kiranya perlu dideteksi berbagai potensi pendukung dan kendala yang dihadapi daerah untuk kemudian dicarikan solusinya dalam konteks pendidikan. Analisis SWOT (Strength, Weakness, Oportunity, and Treatment) adalah strategi awal bagi pemberdayaan dan pengembangan pendidikan di daerah (Fajar, 2005:73-74).

Bagaimana lembaga pendidikan menyambut dan memaknai konsep otonomi daerah dan bagaimana pula mengelola dan mengendalikan suatu lembaga pendidikan terutama dalam manajemen sarana dan prasarana. Memaknai konsep otonomi daerah dalam konteks otonomi pendidikan adalah memberikan kekuasaan dan tanggung jawab penuh kepada sekolah untuk mengatur "rumah tangga"nya sendiri. Otonomi pendidikan menyarankan sekolah untuk memanaj sistem pendidikannya secara mandiri yang lepas dari ketergantungan kepada pemerintah dan kewenangan pusat, menuju ke masyarakat lokal sekolah. Reposisi, sebagai pengalihan kewenagan dari atas (pusat) ke bawah (sekolah) dalam hubungannya dengan penyusunan kurikulum, alokasi keuangan dan sumber daya (berkaitan dengan pengembangan sarana dan prasarana), tenaga pendidik (juga kependidikan), dan peserta didik, serta evaluasi merupakan sesuatu yang harus segera dilakukan bagi peningkatan mutu sekolah dan akuntabilitas lulusan (Fajar, 2005: 76).

Dalam meningkatkan mutu pendidikan sekolah, maka tidak terlepas dari sarana dan prasarana yang ada. Karena sarana dan prasarana yang memadai akan berpengaruh terhadap mutu sekolah. Untuk itu perlu adanya manajemen sarana dan prasarana.

\section{Pengertian Manajemen Sarana dan Prasarana}

Manajamen adalah bagian dan fungsi utama dari administrasi. Sehingga keduanya tak dapat dipisahkan. Ada yang mengartikan administrasi lebih luas daripada manajemen, ada juga yang mengatakan bahwa manajemen lebih luas daripada administrasi. Keduanya benar tergantung dari sudut pandang masing-masing. Secara umum, menurut Prajudi manajemen adalah pengendalian dan pemanfaatan dari pada 
semua faktor dan sumberdaya, yang menurut suatu perencanaan (planning) diperlukan untuk mencapai atau menyelesaikan suatu prapta atau tujuankerja yang tertentu (Atmosudirjo, 1979: 124).

Secara etimologis, menurut Daryanto sarana adalah alat langsung untuk mencapai tujuan. Dan prasarana adalah alat tidak langsung untuk mencapai tujuan (Daryanto, 2005: 51). Menurut rumusan Tim Penyusun Pedoman Pembakuan Media Pendidikan Departemen P \& K tahun 1984 yang dimaksud dengan: "Sarana pendidikan adalah semua fsilitas yang diperlukan dalam proses belajar-mengajar, baik yang bergerak maupun yang tidak bergerak agar pencapaian tujuan pendidikan dapat berjalan dengan lancar, teratur, efektif dan efisien" (Arikunto, 1993: 82).

Sedang menurut Komariyah manajemen sarana dan prasarana adalah manajemen sarana sekolah dan sarana bagi pembelajaran. (Triatna, 2005: 56). Pengertian-pengertian di atas, menurut penulis manajemen sarana dan prasarana pendidikan adalah pengendalian dan pemanfaatan semua faktor dan sumberdaya yang ada baik secara langsung maupun tidak langsung dengan perencanaan yang diperlukan untuk mencapai tujuan pendidikan.

Menurut PP RI No. 19 Tahun 2005 tentang Standar Nasional Pendidikan pasal 24 disebutkan bahwa setiap satuan pendidikan wajib memiliki sarana yang meliputi perabot, peralatan pendidikan, media pendidikan, buku dan sumber belajar lainnya, bahan habis pakai, serta perlengkapan lain yang diperlukan untuk menunjang proses pembelajaran yang teratur dan berkelanjutan. Setiap satuan pendidikan wajib memiliki prasarana yang meliputi lahan, ruang kelas, ruang pimpinan satuan pendidikan, ruang pendidik, ruang tata usaha, ruang perpustakaan, ruang laboratorium, ruang bengkel kerja, ruang unit produksi, ruang kantin, instalasi daya dan jasa, tempat berolahraga, tempat beribadah, tempat bermain, tempat berkreasi, dan ruang/tempat lain yang diperlukan untuk menunjang proses pembelajaran yang teratur dan berkelanjutan (PP. No, 2005: 32-33).

Siapakah yang bertanggung jawab tentang sarana dan prasarana pendidikan? Tidak lain adalah para pengelola pendidikan. Dan secara mikro maka kepala sekolah yang bertanggung jawab dalam masalah ini. Menurut keputusan Menteri P dan K No. 079 / 1975, sarana pendidikan terdiri dari 3 kelompok besar yaitu : 
- Banguna dan perabot sekolah.

- Alat pelajaran yang terdiri, pembukuan dan alat-alat peraga dan laboratorium.

- Media pendidikan yang dikelompokkan menjadi audiovisual yang menggunakan alat penampil dan media yang menggunakan alat penampil (Daryanto, 2005: 51).

Sarana dan prasarana pendidikan sangat menentukan keberhasilan proses pembelajaran. Oleh karena itu, perlu adanya hubungan antara peralatan dan perlengkapan pengajaran dengan program pengajaran yang sesuai dengan standar nasional pendidikan. Dalam PP RI No. 19 tahun 2005 pasal 43 dijelaskan mengenai standar sarana dan prasarana :

- Standar keragaman jenis peralatan laboratorium IPA, laboratorium bahasa, laboratorium komputer, dan peralatan pembelajaran lain pada satuan pendidikan dinyatakan dalam daftar yang berisi jenis minimal peralatan yang harus tersedia.

- Standar jumlah peralatan sebagaimana dimaksud pada ayat (1) dinyatakan dalam rasio minimal jumlah peralatan per peserta didik.

- Standar buku perpustakaan dinyatakan dalam jumlah judul dan jenis buku di perpustakaan satuan pendidikan.

- Standar jumlah buku teks pelajaran di perpustakaan dinyatakan dalam rasio minimal jumlah buku teks pelajaran untuk masing-masing mata pelajaran di perpustakaan satuan pendidikan untuk stiap peserta didik.

- Kelayakan isi, bahasa penyajian, dan kegrafikan buku teks pelajaran dinilai oleh BSNP dan ditetapkan dengan Peraturan Menteri.

- Standar sumber belajar lainnya untuk setiap satuan pendidikan dinyatakan dalam rasio jumlah sumber belajar terhadap peserta didik sesuai dengan jenis sumber belajar dan karakteristik satuan pendidikan. (PP. No, 2005: 33).

\section{Fasilitas Peralatan dan Perlengkapan dengan Pengajaran}

Fasilitas dapat diartikan sebagai segala sesuatu yang dapat memudahkan dan melancarkan pelaksanaan suatu usaha, baik berupa benda maupun uang. Fasilitas secara garis besar dapat dibedakan menjadi dua jenis (Arikunto, 1993: 82).yaitu: 


\section{Mukhroji}

- Fasilitas fisik, yakni segala sesuatu yang berupa benda atau yang dapat dibendakan yang mempunyai peranan untuk memudahkan dan melancarkan sesuatu usaha. Fasilitas fisik disebut juga fasilitas materiil. Contohnya : kendaraan, alat tulis-menulis, alat komunikasi, alat penampil dan sebagainya. Di dalam kegiatan pendidikan yang tergolong dalam fasilitas fisik / materiil antara lain : perabot ruang kelas, perabot kantor tata usaha, perabot dan peralatan laboratorium, perlengkapan perpustakaan, perlengkapan ruang praktek, dan sebagainya.

- Fasilitas uang, yakni segala sesuatu yang bersifat mempermudah suatu kegiatan sebagai akibat bekerjanya nilai uang.

Dalam kegiatan pendidikan peralatan dan perlengkapan pengajaran sangat berpengaruh terhadap proses belajar mengajar. Oleh karena itu jenis peralatan dan perlengkapannya harus disediakan sesuai kebutuhan dan pengadministrasian yang bagus. Sebab bila tidak sesuai dan cara-cara pengadministrasiannya jelek maka akan sangat mengurangi kegunaan alatalat dan perlengkapan tersebut, walaupun peralatan dan perlengkapan itu keadaannya istimewa. Dan titik berat dalam hal ini adalah kepada belajar yang dikaitkan dengan maslah-masalah dan kebutuhan serta kegunaan hasil belajar nanti di dalam kehidupannya. Karena penyediaan sarana pendidikan di suatu sekolah haruslah disesuaikan dengan kebutuhan anak didik serta kegunaan hasilnya di masa-masa yang akan datang.

Salah satu tugas utama kepala sekolah dalam memanaj sarana dan prasarana pendidikan ialah bersama-sama dengan dewan guru dan staf menyusun daftar kebutuhan mereka akan peralatan dan perlengkapan yang dibutuhkan dengan cara a) mempersiapkan perkiraan tahunan untuk diusahakan penyediaannya, kemudian b) menyimpan dan memelihara serta mendistribusikan kepada guru-guru yang bersangkutan, dan menginventarisasi alat-alat/sarana tersebut pada akhir tahun pelajaran (Daryanto, 2005: 52).

Sarana pendidikan merupakan sarana penunjang bagi proses belajarmengajar. Administrasi sarana meliputi: a) perencanaan, b) pengadaan, c) pengaturan, d) penggunaan, e) penyingkiran, dan f) dasar pengetahuan mengenai perpustakaan (Arikunto, 1993: 81-90). 
- Perencanaan

Kapan perencanaan alat pelajaran diadakan? Untuk mengadakan perencanaan kebutuhan alat pelajaran, maka ada tahapan-tahapan tertentu yang harus dilalui, yaitu :

a) Mengadakan analisis terhadap materi pelajaran mana yang membutuhkan alat atau media dalam penyampaiannya. Dari analisis materi ini dapat didaftar alat-alat atau media apa yang dubutuhkan. Ini dilakukan oleh guru-guru bidang studi.

b) Apabila kebutuhan yang diajukan oleh guru-guru ternyata melampaui kemampuan daya beli atau daya pembuatan, maka harus diadakan seleksi menurut skala prioritas terhadap alat-alat yang mendesak pegadaannya. Kebutuhan yang lain dapat dipenuhi pada kesempatan yang lain.

c) Mengadakan inventarisasi terhadap alat atau media yang telah ada. Alat yang sudah ada ini perlu dilihat kembali, lalu mengadakan reinventarisasi. Alat yang perlu diperbaiki atau diubah disendirikan untuk diserahkan kepada orang yang dapat memperbaiki.

d) Mengadakan seleksi terhadap alat atau media yang masih dapat dimanfaatkan, baik dengan reparasi atau modifikasi maupun tidak.

e) Mencari dana (bila belum ada). Kegiatan dalam tahap ini adalah mengadakan perencanaan tentang bagaimana cara memperoleh dana, baik dana rutin maupun non rutin.

f) Menunjuk seseorang (bagian perbekalan) untuk melaksanakan pengadaan alat, yaitu keahlian, kelincahan berkomunikasi, kejujuran dan sebagainya, dan tidak hanya seorang.

Perencanaan yang telah diterangkan di atas berlaku bagi semua sarana yang lain mulai dari prasarana ( tanah pekarangan, gedung, rumah, kelas) dan sarana-sarana lain (perabot, kelengkapan kelas dan kelengkapan ruangan lain). Persyaratan yang harus dipenuhi adalah dapat tercipta dan terpenuhinya pencapaian tujuan pendidikan.

- Pengadaan

Dalam pengadaan alat pelajaran tidak semudah pengadaan meja kursi yang hanya mempertimbangkan selera dan dana yang tersedia. Untuk proses pengadaan alat pelajaran diperlukan pertimbangan yang lebih banyak dan semuanya bersifat edukatif. Pengaturan dan penggunaan 
sarana merupakan dua kegiatan yang tidak dapat dipisahkan, karena dilaksanakan silih berganti. Sehubungan dengan pengaturan dan penggunaan ini, maka sarana dapat dibedakan atas dua kategori, yaitu:

a) Alat-alat yang langsung digunakan dalam proses belajar mengajar seperti alat pelajaran, alat peraga dan media pendidikan.

b) Alat-alat yang tidak langsung terlibat dalam proses belajar mengajar seperti bangunan sekolah, meja guru, perabot kantor tat usaha, kamar kecil dan sebagainya.

Kegiatan pertama yang dilakukan setelah proses pengadaan adalah pencatatan, pemberian nomor kode/nomor inventaris dan pencatatan ke dalam buku daftar inventaris.

- Pengaturan

Pengaturan yang dilakukan sebelum alat-alat ini digunakan disebut pengaturan awal, meliputi:

a) Memberikan identitas pada alat yaitu nomor inventaris dengan kode tertentu untuk jenis tertentu.

b) Pencatatan alat ke dalam buku daftar inventaris. Yang dimaksud dengan buku inventaris adalah buku yang dipergunakan untuk mencatat semua kekayaan, dalam hal ini kekayaan sekolah. Dengan adanya buku inventaris maka pengontrolan dan pengecekan kembali akan dipermudah.

c) Penempatan alat ke dalam almari atau rak yang juga sudah diberi kode. Untuk sekolah yang mempunyai banyak alat, pemisahan didasarkan atas pemisahan dalam almari. Akan tetapi apabila alatnya hanya sedikit, pemisahannya hanya didasrkan atas penempatan pada rak.

- Penggunaan

Sesudah dilakukan pengaturan awal, maka alat-alat ataupun sarana lain sudah siap untuk digunakan. Penggunaan alat diperhitungkan atas adanya empat faktor, yaitu

a) banyaknya alat untuk tiap macam,

b) banyaknya kelas yang menggunakan alat,

c) banyaknya murid pada tiap-tiap kelas, dan

d) banyaknya ruangan atau lokal yang ada di sekolah itu. 
- Penyingkiran Barang

Penyingkiran barang atau penghapusan barang adalah kegiatan yang bertujuan untuk menghapus barang-barang milik negara dari daftar inventaris berdasarkan peraturan perundang-undangan yang berlaku. Untuk melakukan penghapusan atau penyingkiran (afkeur) pelaksana harus memperhatikan tahap-tahap sebagai berikut:

a) Pemilihan barang yang akan dihapuskan dilakukan setiap tahun bersamaan dengan waktu memperkirakan kebutuhan.

b) Memperhitungkan faktor-faktor penyingkiran dan penghapusan ditinjau dari segi nilai uang.

c) Membuat surat pemberitahuan kepada atasan bahwa akan diadakan penyingkiran dengan menyebutkan barang yang hendak disingkirkan.

d) Melaksanakan penyingkiran dengan cara : mengadakan lelangan, penyingkiran harus disaksikan oleh atasan.

e) Membuat berita acara tentang pelaksanaan penyingkiran.

- Dasar Pengetahuan mengenai Perpustakaan

Untuk dapat mencapai hasil yang optimal dalam administrasi sarana maka mereka yang telah diberi tugas atau pekerjaan ini harus memahami dasar pengetahuan mengenai perpustakaan. Untuk dapat memahami dengan mudah tentang perpustakaan (Qalyubi, dkk, 2003: 3-4) ada beberapa istilah yang perlu dipahami terlebih dahulu, yaitu:

a) Pustaka atau buku atau kitab, yaitu kumpulan atau bahan berisi tulisan atau cetakan, dijilid menjadi satu agar mudah dibaca.

b) Perpustakaan, secara konvensional, yaitu kumpulan buku atau bangunan fisik tempat buku dikumpulkan, disusun menurut sistem tertentu untuk kepentingan pemakai.

c) Pustakawan, yaitu orang yang bekerja di perpustakaan atau lembaga sejenisnya dan memiliki pendidikan perpustakaan secara formal (di Indonesia kriteria pendidikan minimal D-2 dalam bidang ilmu perpustakaan, dokumentasi dan informasi.

d) Kepustakaan, yaitu bahan bacaan yang digunakan untuk menyusun karangan, makalah, artikel, laporan ilmiah, dan sejenisnya. 
e) Ilmu perpustakaan, yaitu ilmu yang mengkaji hal-hal yang berkaitan dengan perpustakaan, yang cakupannya meliputi hal-hal sebagai berikut :

f) Perpustakaan sebagai suatu institusi mencakup organisasi perpustakaan, perkembangan, peranan dalam masyarakat, dan sumbangannya pada umat manusia.

g) Kepustakawanan, yaitu hal-hal yang berkaitan dengan pustakawan: profesi kepustakawanan dan penerapan ilmu, misalnya dalam hal pengadaan koleksi, pengolahan, pendayagunaan, penyebaran informasi kepada pemakai.

Oleh karena itu, perpustakaan tidak dapat dipahami sebatas sebuah gedung atau akomodasi fisik tempat menyimpan buku semata, akan tetapi secara sederhana dapat dinyatakan bahwa perpustakaan adalah suatu unit kerja yang memiliki sumber daya manusia,"ruang khusus" dan kumpulan koleksi sesuai dengan jenis perpustakaannya. Perpustakaan harus dipahami sebagai sebuah sistem yang di dalamnya terdapat unsur tempat (institusi), koleksi yang disusun berdasarkan sistem tertentu, dan pemakai.

\section{Penutup}

Sekolah yang sarana-prasarananya dimanaj dengan baik akan berbeda dengan sekolah yang sarana-prasarananya kurang dimanaj dengan baik. Sarana yang dimanaj dengan baik akan menampilkan kenyamanan, keindahan, kemutakhiran, dan kemudahan dalam penggunaannya. Dengan adanya otonomi daerah, baik daerah maupun lembaga pendidikan yang di daerah tersebut terkena imbasnya. Mereka mau tidak mau harus menerima dengan konsekuensi dan siap untuk mengurusi rumah tangga daerah sendiri. Lembaga pendidikan dengan adanya otonomi di bidang pendidikan harus mampu mengembangkan dan mencukupi kebutuhan sendiri dengan mengerahkan segala potensi yang ada, baik sumber daya alam, sumber daya manusia maupun sumber-sumber yang lain.

Untuk bisa mandiri dengan segala keterbatasan dan kekurangan yang dimilikinya dan juga kekuatan dan tantangan serta peluang yang ada, maka dengan analisis SWOT sangat membantu untuk mengatasi permasalahan yang dihadapinya. Penggunaan teknik ini diharapkan dapat menghasilkan 
suatu rekomendasi yang lebih komprehensif yang terkait dengan kebijakan dalam pendidikan.

Sarana dan prasarana yang ada dalam suatu lembaga pendidikan agar dapat memberikan manfaat yang optimal maka harus dikelola dengan baik dan profesional. Artinya dalam pelaksanaannya harus diserahkan pada mereka yang betul-betul memiliki pengetahuan tentang sarana dan prasarana dan mampu melaksanakan tugasnya dengan penuh tanggung jawab dan dapat dipercaya. Sehingga dengan manajemen sarana dan prasarana yang baik, sebuah lembaga pendidikan mampu meningkatkan mutu pendidikannya masing-masing dengan out put yang dapat diandalkan.

\section{DAFTAR PUSTAKA}

A, Malik Fajar, Holistika Pemikiran Pendidikan/Ed. Ahmad Barizi, Jakarta: PT Raja Grafindo Persada, 2005.

Chan, Sam M., Tuti T. Sam, Analisis SWOT: Kebijakan Pendidikan Era Otonomi Daerah, Jakarta: PT Raja Grafindo Persada, 2005.

Daryanto, Administrasi Pendidikan, Jakarta; Rineka Cipta, 2005.

H.A.R. Tilaar, Membenahi Pendidikan Nasional, Jakarta: Rineka Cipta, 2002.

, Paradigma Baru Pendidikan Nasional, Jakarta: Rineka Cipta, 2000.

PP. RI No. 19, Standar Nasional Pendidikan, Jakarta: Cemerlang, 2005.

Prajudi Atmosudirjo, Dasar-dasar Ilmu Administrasi II, Jakarta: 1979.

Suharsimi Arikunto, Organisasi dan Administrasi Pendidikan Teknologi dan Kejuruan, Jakarta: PT. Raja Grafindo Persada, 1993.

Syihabudin Qalyubi, dkk, Dasar-dasar Ilmu Perpustakaan dan Informasi, Yogyakarta: IAIN Sunan Kalijaga, 2003. 
Mukhroji

64

AnBanTa vol 16, Na 1, Januari-Aprilzail 